CZASOPISMO INŻYNIERII LĄDOWEJ, ŚRODOWISKA I ARCHITEKTURY JOURNAL OF CIVIL ENGINEERING, ENVIRONMENT AND ARCHITECTURE JCEEA, t. XXXIII, z. 63 (3/16), lipiec-wrzesień 2016, s. 497-506

\author{
Dawid TĄTA ${ }^{1}$ \\ Henryk FOIT ${ }^{2}$
}

\title{
POSZUKIWANIE NAJKORZYSTNIEJSZEJ WIELKOŚCI OKIEN BUDYNKU PASYWNEGO
}

\begin{abstract}
Podczas projektowania budynku, projektant musi rozwiązać wiele kluczowych problemów. Jednym z takich problemów jest ustalenie wielkości okien. Prócz rozwiązania kwestii estetycznych, należy się zastanowić jak wielkość okien będzie wpływać na bilans cieplny budynku. Zwiększanie powierzchni przeszkleń z jednej strony zwiększa straty ciepła (współczynnik $U$ okna jest znacznie większy niż ściany, w której okno zlokalizowano - okno posiada mniejsze właściwości izolacyjne), z drugiej potęguje bierne zyski ciepła od promieniowania słonecznego. Zyski takie są pożądane w okresach zimnych (zmniejszają zapotrzebowanie na ciepło pomieszczenia), jednak w okresach letnich mogą powodować nadmierne przegrzewanie. Poniższa praca jest próbą wskazania wielkości okna zewnętrznego elewacji południowej budynku pasywnego. W analizach wykorzystano przykładowy model budynku, a obliczenia prowadzono przy pomocy programu ESP-r. Analizowano różne powierzchnie przeszkleń oraz różne wielkości zacienień okien elewacji południowej. Powierzchnię przeszkleń odnoszono do całkowitej powierzchni ściany zewnętrznej danego pomieszczenia - rozpatrywano przypadki, w których powierzchnia szklenia odpowiadała od $15 \%$ do $50 \%$ całkowitej powierzchni ściany. Dla każdej wielkości okna prowadzono dodatkowo obliczenia wpływu 4 wielkości zacienień: $0,5 \mathrm{~m}, 1 \mathrm{~m}, 1,5 \mathrm{~m}$, $2 \mathrm{~m}$, a także przypadku okna niezacienionego. Badania prowadzono w kierunku określenia zapotrzebowania na energię do ogrzewania oraz chłodzenia. Zgodnie z przewidywaniami zwiększanie udziału przeszklenia ściany zmniejsza się zapotrzebowanie na ciepło pomieszczenia, jednak znacząco wzrasta zapotrzebowanie na energię do chłodzenia.
\end{abstract}

Słowa kluczowe: wielkość okien, budynek pasywny, ESP-r, zacienienia, gruntowy wymiennik ciepła, ogrzewanie budynku pasywnego, chłodzenie budynku pasywnego, wentylacja

\footnotetext{
${ }^{1}$ Autor do korespondencji / corresponding author: Dawid Tąta, Politechnika Śląska, Katedra Ogrzewnictwa, Wentylacji i Techniki Odpylania, ul. Konarskiego 20, 44-100 Gliwice; tel. 322372395; dawid.tata@polsl.pl

${ }^{2}$ Henryk Foit, Politechnika Śląska, Katedra Ogrzewnictwa, Wentylacji i Techniki Odpylania, ul. Konarskiego 20, 44-100 Gliwice
} 


\section{Wstęp}

Projektowanie budynku wiąże się z koniecznością rozwiązania wielu problemów. Jednym z nich jest wielkość okien. Z jednej strony duże okna zapewniają dobre oświetlenie pomieszczeń promieniami słonecznymi oraz nagrzewanie pomieszczeń zlokalizowanych w południowej części budynku. Z drugiej strony przeszklenia powodują większe straty ciepła (szyby okienne cechują się niższą izolacyjnością cieplną w porównaniu do ścian), natomiast w okresie letnim mogą powodować przegrzanie pomieszczeń wynikające z przedostawania się dużej ilości promieniowania słonecznego do pomieszczeń.

Próba wskazania korzystnego stosunku wielkości okna względem powierzchni ściany zewnętrznej, w której okno zostało zlokalizowane jest tematem tego opracowania. W celu określenia optymalnej wielkości okien dla budynku pasywnego przeprowadzono symulacje numeryczne w programie ESP-r [1, 2]. W czasie symulacji zmieniano wielkość okien oraz wielkość elementów zacieniających w postaci balkonu nad parterem i strzechy dachu, tak aby uzyskać konfigurację optymalną.

\section{Budynek}

Obliczenia przeprowadzono dla budynku, który ma wiernie oddać charakterystykę budynku pasywnego. Obliczenia przeprowadzono dla wszystkich pomieszczeń budynku. Jedynym zmiennym parametrem była wielkość okien pomieszczeń znajdujących się po stronie południowej. Dodatkowo wszystkie pomieszczenia od strony południowej miały te same wymiary, różniły się jedynie położeniem. Przyjęte założenia miały na celu uniezależnienie wyników końcowych od cech specyficznych budynku.

$\mathrm{Na}$ rysunku 1 przedstawiono rzuty kondygnacji budynku, a na rysunku 2 umieszczono wizualizację domu od strony wschodnio-południowej. Rzuty oraz wizualizację przygotowano przy pomocy programu InterSoft ArCADia START 6.5. Natomiast w tabeli 1 zestawiono powierzchnie poszczególnych pomieszczeń.

Tabela 1. Powierzchnie pomieszczeń

Table 1. Surfaces spaces

\begin{tabular}{|c|c||c|c|}
\hline \multicolumn{2}{|c||}{ Parter } & \multicolumn{2}{c|}{ Piętro } \\
\hline Pomieszczenie & Powierzchnia & Pomieszczenie & Powierzchnia \\
\hline Pokój 1 & $16,40 \mathrm{~m}^{2}$ & Pokój 3 & $16,40 \mathrm{~m}^{2}$ \\
\hline Pokój 2 & $16,40 \mathrm{~m}^{2}$ & Pokój 4 & $16,40 \mathrm{~m}^{2}$ \\
\hline Kuchnia & $16,40 \mathrm{~m}^{2}$ & Pokój 5 & $16,40 \mathrm{~m}^{2}$ \\
\hline Toaleta dolna & $7,67 \mathrm{~m}^{2}$ & Toaleta górna & $7,67 \mathrm{~m}^{2}$ \\
\hline Wiatrołap & $7,99 \mathrm{~m}^{2}$ & Hol górny & $13,50 \mathrm{~m}^{2}$ \\
\hline Hol dolny & $13,30 \mathrm{~m}^{2}$ & Łazienka & $7,82 \mathrm{~m}^{2}$ \\
\hline Schody & $4,64 \mathrm{~m}^{2}$ & & \\
\hline
\end{tabular}

*schody zostały ujęte w specyfikacji pomieszczeń parteru, w stropie piętra w tym miejscu znajduje się otwór 

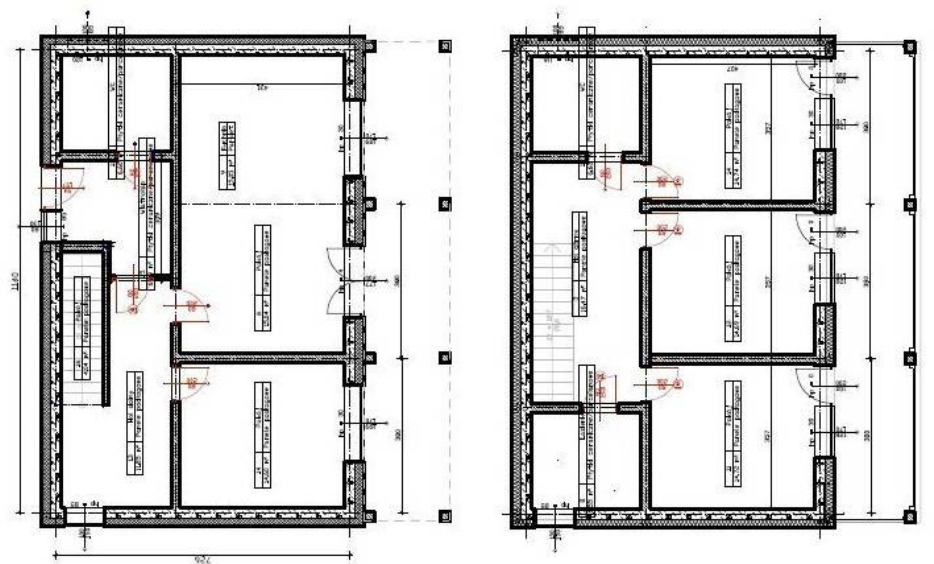

Rys. 1. Rzuty budynku. W lewej części parter, po prawej pierwsze piętro

Fig. 1. Building project. On the left first-floor, on the right the floor

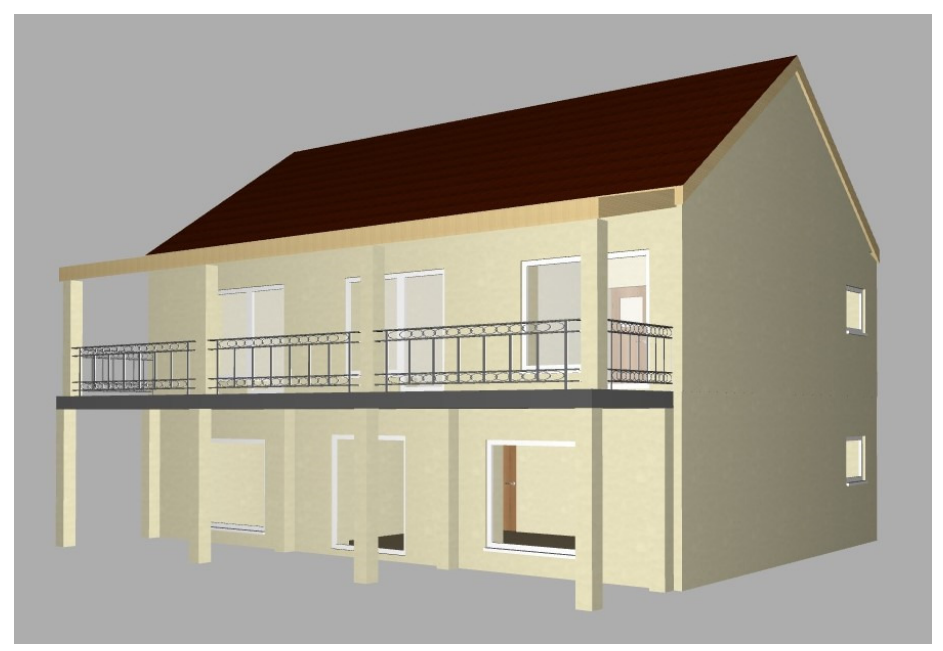

Rys. 2.Wizualizacja budynku

Fig. 2. Visualization of the building

\subsection{Konstrukcja przegród}

W czasie obliczeń wprowadzono do programu 7 własnych konstrukcji przegród oraz skorzystano z jednej domyślnej (strop pomiędzy piętrami). Konstrukcje przegród przedstawiają się następująco: 
1. Ściany zewnętrzne

\begin{tabular}{|c|c|c|}
\hline Materiał & $\begin{array}{c}\lambda \\
\mathrm{W} /(\mathrm{mK})\end{array}$ & $\begin{array}{c}\text { Grubość warstwy } \\
\mathrm{mm}\end{array}$ \\
\hline Tynk wewnętrzny & 0,350 & 13 \\
\hline Bloczek YTONG & 0,095 & 365 \\
\hline Styropian & 0,040 & 250 \\
\hline Tynk zewnętrzny & 0,840 & 15 \\
\hline
\end{tabular}

2. Ściany wewnętrzne

\begin{tabular}{|c|c|c|}
\hline Materiał & $\begin{array}{c}\lambda \\
\mathrm{W} /(\mathrm{mK}) \\
\end{array}$ & $\begin{array}{c}\text { Grubość warstwy } \\
\mathrm{mm}\end{array}$ \\
\hline Tynk wewnętrzny & 0,350 & 13 \\
\hline Cegła & 0.940 & 250 \\
\hline Tynk wewnętrzny & 0,350 & 13 \\
\hline
\end{tabular}

3. Przegroda wirtualna - zastosowana dla oddzielenia kuchni od pokoju 2 oraz oddzielenia klatki schodowej od pozostałych pomieszczeń. Domyślnie w tym miejscu nie znajduje się żadna przegroda, jednak w programie należało wprowadzić rozdział stref obliczeniowych; przegroda ta została zamodelowana jako papierowa, tak aby nie wpływała na przepływ ciepła.

4. Podłoga na gruncie

\begin{tabular}{ccc}
\hline Materiał & $\lambda$ & Grubość warstwy \\
& $\mathrm{W} /(\mathrm{mK})$ & $\mathrm{mm}$ \\
\hline Podsypka żwirowa & 0,360 & 200 \\
Folia PVC & 0,160 & 10 \\
Wełna mineralna & 0,100 & 400 \\
Folia PVC & 0,160 & 10 \\
Podkład betonowy & 1,400 & 150 \\
Folia PVC & 0,160 & 10 \\
Wełna mineralna & 0,100 & 400 \\
Wylewka z chudego betonu & 0,380 & 30 \\
Wykończenie podłogi & 1,500 & 12 \\
\hline
\end{tabular}

Całkowita grubość przegrody wynosi $122,2 \mathrm{~cm}$, a współczynnik $U=0,108 \mathrm{~W} /\left(\mathrm{m}^{2} \cdot \mathrm{K}\right)$ - współczynnik wyznaczony przez program ESP-r.

5. Szklenie okien - szklenie zadano w programie jako zespół 3 szyb o grubości $6 \mathrm{~mm}$, rozdzielonych warstwami powietrza o grubości $16 \mathrm{~mm}$. Współczynnik $U=0,590 \mathrm{~W} /\left(\mathrm{m}^{2} \cdot \mathrm{K}\right)$. Rama okienna została zamodelowana $\mathrm{w}$ programie $\mathrm{z}$ wykorzystaniem gotowej konstrukcji ramy izolowanej cieplnie. 
6. Strop pomiędzy piętrem a nieużytkowym poddaszem

\begin{tabular}{ccc}
\hline Materiał & $\lambda$ & Grubość warstwy \\
& $\mathrm{W} /(\mathrm{mK})$ & $\mathrm{mm}$ \\
\hline Konstrukcja stropowa* & 0,380 & 100 \\
Styropian & 0,040 & 250 \\
\hline
\end{tabular}

* - konstrukcja stropowa wybrana z bazy konstrukcji programu.

Całkowita grubość przegrody wynosi $35 \mathrm{~cm}$, a współczynnik $U=0,126 \mathrm{~W} /\left(\mathrm{m}^{2} \cdot \mathrm{K}\right)$ - współczynnik wyznaczony przez program ESP-r.

7. Dach - w programie ESP-r uwzględniono przegrodę o konstrukcji drewnianej, izolowanej wełną mineralną, z folią PCV i pokryciem ceramicznym. Współczynnik $U=0,160 \mathrm{~W} /\left(\mathrm{m}^{2} \cdot \mathrm{K}\right)$.

8. Strop między piętrami - w obliczeniach uwzględniono gotowy strop żelbetonowy $\mathrm{z}$ odpowiednią izolacją cieplną $\mathrm{i}$ warstwami wierzchnimi. Współczynnik $U=0,126 \mathrm{~W} /\left(\mathrm{m}^{2} \cdot \mathrm{K}\right)$.

\section{Założenia obliczeń}

Wymiary ściany zewnętrznej (elewacji) przypadającej na jedno pomieszczenie od strony południowej wynoszą $3,8 \mathrm{~m} \mathrm{x} 2,8 \mathrm{~m}$ (szerokość x wysokość), co daje powierzchnię $10,64 \mathrm{~m}^{2} \mathrm{w}$ tym powierzchnia okien.

Powierzchnia szklenia okna balkonowego jest równa $1,55 \mathrm{~m}^{2}$ $(1,84 \mathrm{~m} \times 0,84 \mathrm{~m})$. Taka powierzchnia okna jest wielkością początkową w obliczeniach - powierzchnia okien na parterze została dobrana podobnie, z uwzględnieniem odsunięcia okna od gruntu oraz początkowej wysokości okna równej $1,7 \mathrm{~m}$. Kolejne wielkości szkleń są ustalane na podstawie procentowego udziału szklenia. Na tej podstawie obliczano całkowitą powierzchnię szklenia.

Wartością graniczną w obliczeniach jest powierzchnia szklenia stanowiąca $50 \%$ całkowitej powierzchni południowej ściany zewnętrznej pomieszczeń. Jest to graniczna wielkość, większe udziały powierzchni okna w powierzchni ściany wymagają zwiększania wysokości okna. ko:

Kolejne prace dla pomieszczeń na parterze i piętrze prowadzone były dwoja-

Parter - uzyskaną powierzchnie szklenia przyjmowano wprost jako powierzchnię szklenia okna w danym pomieszczeniu (w przypadku pokoju dziennego była to powierzchnia szklenia okna balkonowego, w pozostałych dwóch pomieszczeniach powierzchnia okna zwyktego.

Piętro - od uzyskanej powierzchni szklenia odejmowano powierzchnię szklenia okna balkonowego (wielkość stała dla wszystkich przypadków) i uzyskana różnica była powierzchnią szklenia dodatkowego okna.

W tabeli 2 podano powierzchnie szklenia okien w poszczególnych przypadkach obliczeniowych. 
Tabela 2. Zestawienie powierzchni szkleń

Table 2. The specification of area glazing

\begin{tabular}{|c|c|c|}
\hline $\begin{array}{c}\text { Numer przy- } \\
\text { padku }\end{array}$ & $\begin{array}{c}\text { Procentowy } \\
\text { udział szklenia }\end{array}$ & $\begin{array}{c}\text { Powierzchnia } \\
\text { szklenia }\end{array}$ \\
\hline 1. & $14,53 \%$ & $1,55 \mathrm{~m}^{2}$ \\
\hline 2. & $20 \%$ & $2,13 \mathrm{~m}^{2}$ \\
\hline 3. & $25 \%$ & $2,66 \mathrm{~m}^{2}$ \\
\hline 4. & $30 \%$ & $3,19 \mathrm{~m}^{2}$ \\
\hline 5. & $35 \%$ & $3,72 \mathrm{~m}^{2}$ \\
\hline 6. & $40 \%$ & $4,26 \mathrm{~m}^{2}$ \\
\hline 7. & $45 \%$ & $4,79 \mathrm{~m}^{2}$ \\
\hline 8. & $50 \%$ & $5,32 \mathrm{~m}^{2}$ \\
\hline
\end{tabular}

\section{Dodatkowe założenia obliczeniowe:}

- szerokość ramy okiennej wynosi $8 \mathrm{~cm}$ z każdej strony;

- okna balkonowe umieszczone są $4 \mathrm{~cm}$ powyżej powierzchni podłogi, a okna zwykłe $30 \mathrm{~cm}$ powyżej podłogi;

- okna na parterze są lokalizowane centralnie w przegrodzie, w przypadku pomieszczeń na piętrze okno balkonowe jest zlokalizowane w lewej części ściany zewnętrznej (patrząc od wewnątrz pomieszczenia) odsunięte od ściany działowej o $5 \mathrm{~cm}$, a okna zwykłe są niejako przedłużeniem okna balkonowego.

\subsection{Wentylacja}

Zgodnie z wytycznymi dla budynków pasywnych, w analizach założono wentylację nawiewno-wywiewną, wyposażoną w rekuperator i gruntowy wymiennik ciepła. W obliczeniach założono wentylację pomieszczeń strumieniem powietrza wentylacyjnego wymaganego ze względów higienicznych. Przyjęto pracę rekuperatora o sprawności $90 \%$. Temperaturę powietrza nawiewanego założono jako $20^{\circ} \mathrm{C}$.

Podczas wyznaczania zapotrzebowania na energię do chłodzenia pomieszczeń nie uwzględniano działania rekuperatora ani gruntowego wymiennika ciepła. Takie założenie pozwala określić zapotrzebowanie na chłód, które powinno być podstawą doboru gruntowego wymiennika ciepła. W przypadku gruntowego wymiennika ciepła omijanie przez świeże powietrze rekuperatora w okresach wysokich temperatur ma na celu uniknięcie podgrzania powietrza $\mathrm{w}$ rekuperatorze. Innymi słowy, gruntowy wymiennik ciepła powinien być tak zaprojektowany, aby mógł umożliwić schłodzenie powietrza odpowiadające wyznaczonemu zapotrzebowaniu na chłód.

\subsection{Ogrzewanie i chłodzenie}

Na potrzeby obliczeń programem ESP-r założono ogrzewanie oparte o indywidualne źródła ciepła dla wszystkich pomieszczeń. Przyjęto indywidualną regulację ogrzewania. Jedyną przestrzenią nieogrzewaną w budynku stanowi nieużyt- 
kowe, niedostępne dla domowników poddasze. Nie przyjmowano konkretnego typu źródeł ciepła (jak grzejnik elektryczny, czy wodny). Podobne założenia podjęto dla systemu chłodzenia: każde pomieszczenie chłodzone indywidualne $\mathrm{z}$ indywidualną regulacją.

Zapotrzebowanie na ciepło do ogrzewania oraz energię potrzebną do chłodzenia są wartościami wynikowymi analizy.

\subsection{Zacienienia}

W analizach dokonano obliczeń dla różnych wielkości okien, a także rozważano wpływ zmieniających się wielkości zacienień okien elewacji południowej. Rozpatrywano zacienienia o wysięgu $0,5 \mathrm{~m}, 1 \mathrm{~m}, 1,5 \mathrm{~m}, 2 \mathrm{~m}$ (model startowy nie posiadał żadnych zacienień). Zacienienia tworzą balkony (zacienienie okien parteru) oraz okapu dachu - zacienienie okien pomieszczeń piętra. W programie zacienienia utworzono przy pomocy funkcji solar obstruction dostępnych dla poszczególnych pomieszczeń. Tak utworzone zacienienia nie wpływają na bilans strat ciepła przez przegrody - zacienienia nie uczestniczą w przekazywaniu ciepła z pomieszczenia do otoczenia.

\section{Dane klimatyczne}

Dane klimatyczne przyjęte do obliczeń odpowiadają reprezentatywnemu rokowi, opracowanemu na podstawie danych klimatycznych z 30-sto lecia. Reprezentatywne przebiegi roczne uzyskano przez zestawienie miesięcznych przebiegów, wybranych z 30 miesięcy związanych z okresem $1966 \div 1996$. Podstawowym kryterium wyboru była średnia temperatura miesięczna porównywana ze średnimi temperaturami miesięcznymi z 30-sto lecia. Kryteriami dodatkowymi była średnia suma miesięczna promieniowania całkowitego na płaszczyznę poziomą porównywana z odpowiadającą jej średnią z wielolecia, średnia miesięczna prędkość wiatru porównywana ze średnimi z wielolecia oraz średnia miesięczna wartość amplitudy wahań dobowych temperatury porównywana $\mathrm{z}$ odpowiadającymi jej średnimi z wielolecia.

\section{Wyniki obliczeń}

Analizę $\mathrm{z}$ wykorzystaniem programu ESP-r prowadzono dwutorowo. $\mathrm{W}$ pierwszym przypadku obliczenia prowadzono w kierunku określenia zapotrzebowania na ciepło na potrzeby ogrzewania budynku. W tym przypadku w programie ESP-r kontrola systemu ogrzewania i chłodzenia została dobrana tak, aby ogrzewanie utrzymywało minimalną temperaturę powietrza równą $20^{\circ} \mathrm{C}$ $\left(24^{\circ} \mathrm{C}\right.$ w przypadku łazienki i WC). Maksymalną moc cieplną urządzenia grzewczego dla każdego pomieszczenia ustalono na stosunkowo wysokim poziomie, dzięki czemu istniała pewność, iż nie dojdzie do niedogrzania pomieszczenia. Równocześnie system chłodzenia ograniczono ustawiając wysoką temperaturę jego włączenia - dawało to pewność, iż w tych analizach system chłodzenia nie uruchomi się. 
Przeprowadzono również analizę zapotrzebowania na energię na potrzeby chłodzenia. Podczas tych prac sterowanie systemu odwrócono - ustawiono parametry włączenia systemu chłodzenia tak, aby temperatura $\mathrm{w}$ pomieszczeniach nie przekraczała $23^{\circ} \mathrm{C}\left(26^{\circ} \mathrm{C}\right.$ w przypadku łazienki i WC), a temperaturę uruchomienia systemu grzewczego ustalono na odpowiednio niską, dzięki czemu wyeliminowano możliwość uruchomienia ogrzewania. Temperatury dobrano zgodnie $\mathrm{z}$ temperaturami zamieszczonymi $\mathrm{w}$ normie PN-B-03421[3]. Analiza systemu chłodzenia została przeprowadzona w celu pozyskania danych do dalszych analiz, wyniki nie są decydujące o wnioskach tej pracy.

Każde pomieszczenie budynku tworzyło osobną strefę, dla której obliczano zapotrzebowanie na energię, osobno na potrzeby ogrzewania i chłodzenia.

\subsection{Wpływ wielkości okna na zapotrzebowanie na ciepło}

Uzyskane wyniki zestawiono na rysunku 3. Zgodnie z przewidywaniami, wraz z zwiększaniem powierzchni okna (dla przypadku bez zacienień) maleje zapotrzebowanie na ciepło - intensyfikowane są zyski ciepła od promieniowania słonecznego. Rezultat taki związany jest z przyjętymi współczynnikami $U$ okien i przegród zewnętrznych pełnych rozpatrywanego budynku. Natomiast pojawienie się i zwiększanie zacienienia powoduje zwiększenie zapotrzebowania na energię do ogrzewania. Zacienienia zmniejszają zyski ciepła od promieniowania słonecznego, co było spodziewane.

Analizując wyniki prowadzonych obliczeń można dojść do wniosku, iż najkorzystniejszym rozwiązaniem jest maksymalna możliwa wielkość okien i brak zacienień. Taki układ może prowadzić do okresowych przegrzań pomieszczeń w okresach letnich, przeciwdziałać temu będzie gruntowy wymiennik ciepła, wspomagany układem chłodniczym - te elementy będą analizowane podczas dalszych prac.

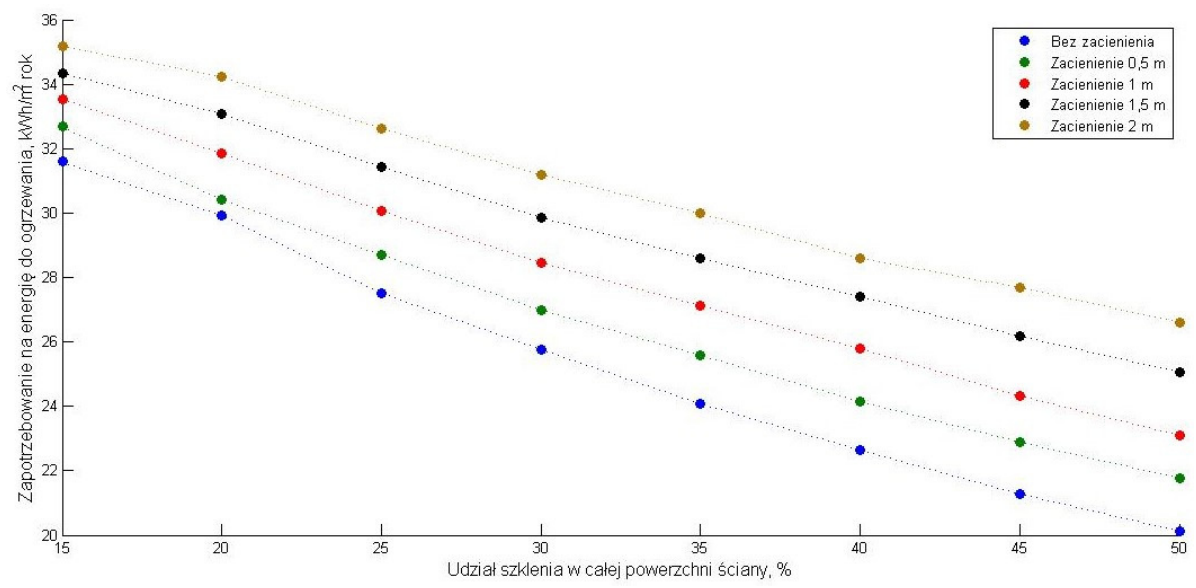

Rys. 3. Zapotrzebowanie na energię do ogrzania

Fig. 3. The demand for energy for heating 


\subsection{Wpływ wielkości okna na zapotrzebowanie na energię do chłodzenia}

Równolegle prowadzone obliczenia zapotrzebowania na energię do chłodzenia dały, zgodnie z przewidywaniami, niemal całkowicie odwrotne wyniki. Rysunek 4 przedstawia układ wyników, z którego widać, iż wraz ze zwiększającą się powierzchnią okien wzrasta zapotrzebowanie na energię do chłodzenia budynku. Wprowadzenie zacienień poprawia sytuację - zapotrzebowanie na energię maleje wraz ze wzrostem zacienień.

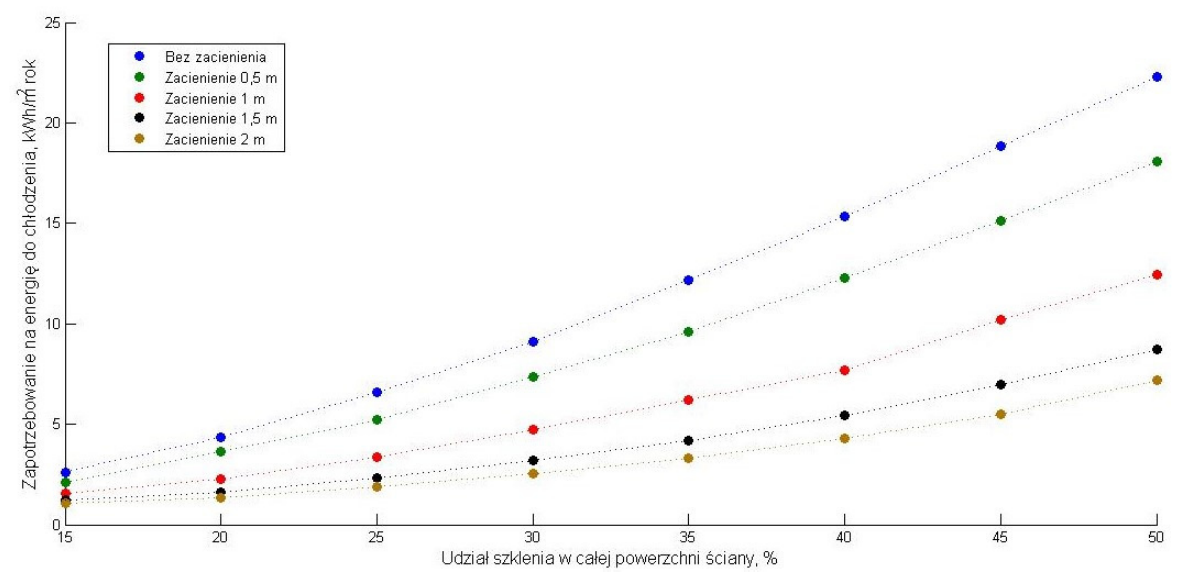

Rys. 4. Zapotrzebowanie na energię do chłodzenia

Fig. 4. The demand for energy for cooling

Okresowemu przegrzewaniu pomieszczeń może przeciwdziałać układ chłodzenia oparty o aktywne urządzenia chłodzące lub pasywne jak np. gruntowy wymiennik ciepła. W przypadku budynku wyposażonego w odpowiednio dobrany gruntowy wymiennik ciepła, zapewniający pasywne chłodzenie wydaje się możliwe rozwiązanie problemu usuwania nadmiaru zysków ciepła przy znacznych przeszkleniach ścian. W takim rozwiązaniu minimalizowane będą koszty związane z zaopatrzeniem w ciepło, przy jednoczesnym naturalnym chłodzeniu. Ograniczeniem w tym rozwiązaniu jest dostępna wielkość gruntowego wymiennika ciepła, który miałby odpowiadać za chłodzenie. Jeśli wielkość GWC jest ograniczona należałoby wprowadzić zacienienia okien. W prezentowanej pracy zapotrzebowanie na energię do chłodzenia wyznaczano w celu określenia właściwej wielkości gruntowego wymiennika ciepła lub ewentualnego dodatkowego systemu chłodzenia.

W przeprowadzonych analizach pominięto koszty energetyczne dotyczące działania gruntowego wymiennika ciepła i rekuperatora.

\section{Podsumowanie}

Dobór wielkości okien elewacji południowej budynku pasywnego (a także energooszczędnego) jest skomplikowanym problem. Wskazanie jednoznacznego rozwiązania jest niezwykle trudne. Wybór rozwiązania ostatecznego jest zależny 
od wielu czynników, wśród których należy wyróżnić: dokładne położenie geograficzne budynku (które będzie wpływać na zyski ciepła od słońca), konstrukcji budynku (izolacyjności przegród zewnętrznych), a nawet instalacji, w które budynek jest wyposażony, jak np. zastosowanie gruntowego wymiennika ciepła, czy elementy zacieniania.

Możliwe jest wskazanie orientacyjnej optymalnej wielkości okien dla konkretnego rozwiązania budynku. $\mathrm{W}$ przypadku budynku wyposażonego $\mathrm{w}$ gruntowy wymiennik ciepła, którego wymiary nie są ograniczane można dopuścić montaż okien o maksymalnej możliwej powierzchni, dodatkowo wyposażanych w aktywne zacienienie, np. w postaci rolet. Jeśli wielkość GWC jest ograniczona, najkorzystniejszego rozwiązania związane jest z przeszkleniem nie przekraczającym $40 \div 45 \%$ powierzchni ściany i wysięgiem elementów zacieniających o szerokości 1,5 m. Dokładnego określenia tych wielkości wymaga sprecyzowanie wielkości gruntowego wymiennika ciepła.

\section{Literatura}

[1] The ESP-r System for Building Energy Simulation User Guide Version 10 Series, ESRU Manual U02/1, Wydawca: University of Strathclyde, 2002.

[2] Hensen, J.L.M.: On System Simulation for Building Performance Evaluation, Building Performance Simulation Association, 1995.

[3] Norma PN-B-03421:1978: Wentylacja i klimatyzacja -- Parametry obliczeniowe powietrza wewnętrznego $\mathrm{w}$ pomieszczeniach przeznaczonych do stałego przebywania ludzi. Norma wycofana.

\section{RESEARCH OF OPTIMUM WINDOWS SIZE IN PASSIVE BUILDING}

While designing a building, the designer has to resolve a number of key issues. One of these issues is to determine the size of windows. In addition to solving aesthetic aspect, we should ponder how the windows' size will affect the thermal balance of the building. On one hand, increasing the glazing area increases heat losses (window's U coefficient is much larger than wall's in which the window is located - window has lower insulating properties), but on the other hand it intensifies passive heat gains from solar radiation. Such gains are desired during cold periods (they reduce room's heat demand), however during summer periods they can cause excessive overheating. This research is an attempt to indicate the size of external window of passive building's south facade. In the analysis, the exemplary building model was used and the calculations were carried out with the use of ESP-r software. Various areas of glazing and windows' shading of south facade were analyzed. The glazing surface was compared with the total surface of given room's external wall - the cases in which glazing surface corresponded to $15 \%$ to $50 \%$ of wall's total surface were considered. For each window's size the additional calculations of the impact of 4 shading sizes: $0,5 \mathrm{~m}, 1 \mathrm{~m}$, $1,5 \mathrm{~m}, 2 \mathrm{~m}$, as well as the case of window without shading, were carried out. The research was conducted in the direction of determining energy demand for heating and cooling. As expected, increasing wall's glazing reduces room's heat demand, however, the demand for cooling energy rises.

Keywords: passive house, ESP-r, shading, ground heat exchanger, heating, cooling, ventilation

DOI: $10.7862 / \mathrm{rb} .2016 .233$

Przestano do redakcji: $30.06 .2016 r$.

Przyjęto do druku: $30.11 .2016 r$. 